ASIMTOT: JURNAL KEPENDIDIKAN MATEMATIKA

Volume 2 Nomor 2, Juni - November 2020, halaman 129 - 138

Tersedia Daring pada https://journal.unwira.ac.id/index.php/ASIMTOT

\title{
STUDI LITERATUR: PENINGKATAN KEMAMPUAN BERPIKIR KRITIS MATEMATIS SISWA MELALUI PENDEKATAN CONTEXTUAL TEACHING AND LEARNING (CTL)
}

\author{
Paskalia Yasinta ${ }^{1}$, Etriana Meirista ${ }^{2}$, Abdul Rahman Taufik $^{3}$ \\ Pendidikan Matematika, Fakultas Keguruan dan Ilmu Pendidika, Universitas Musamus Merauke \\ yasinta.lanar@gmail.com ${ }^{1}, \underline{\text { etriana @ unmus.ac.id }}$, $\underline{\text { taufik_fkip@ } \text { unmus.ac.id }^{3}}$
}

\begin{abstract}
Abstrak: Penelitian ini bertujuan untuk menjelaskan pendekatan Contextual Teaching and Learning (CTL) yang diterapkan dalam pembelajaran matematika dengan menggunakan studi literatur. Sumber data dalam penelitian ini ditempuh melalui riset kepustakaan murni berupa data sekunder dengan mengkaji sumber-sumber tertulis seperti jurnal-jurnal ilmiah. Teknik analisis data dalam penelitian ini melalui beberapa tahap, yaitu meringkas data, menarik berbagai topik pembahasan, mengembangkan data berdasarkan kepentingannya, melakukan cross check, memaparkan hasil yang telah dihimpun dan menarik kesimpulan. Hasil penelitian menunjukkan bahwa pendekatan Contextual Teaching and Learning (CTL) pada tahapan pembelajaran memiliki relevansi dengan indikator kemampuan berpikir kritis matematis, yaitu mampu menganalisis, merumuskan pokok permasalahan, menentukan strategi, memeriksa kembali dan menyimpulkan masalah yang diberikan. Selain itu jika dikaitkan dengan kategori PAM, kategori siswa berkemampuan tinggi memberikan kontribusi peningkatan kemampuan berpikir kritis matematis lebih tinggi bila dibandingkan dengan kategori siswa kemampuan sedang maupun siswa kemampuan rendah. Selanjutnya jika dikaitkan dengan tingkat pendidikan, kemampuan berpikir kritis matematis siswa SMP dan SMA melalui pendekatan CTL mengalami peningkatan kemampuan berpikir kritis matematis yang cukup baik. Sehingga dapat disimpulkan bahwa pendekatan CTL mampu meningkatkan kemampuan berpikir kritis matematis saat diterapkan dalam pembelajaran matematika.
\end{abstract}

Kata kunci: Contextual Teaching and Learning (CTL), Kemampuan Berpikir Kritis Matematis.

Abstract: This study aims to explain the Contextual Teaching and Learning (CTL) approach applied in mathematics learning using literature studies. The source of the data in this study was pursued through pure library research in the form of secondary data by examining written sources such as scientific journals. The data analysis technique in this study went through several stages, namely summarizing the data, drawing various discussion topics, developing data based on their importance, conducting cross-checks, presenting the compiled results, and drawing conclusions. The results showed that the Contextual Teaching and Learning (CTL) approach at the learning stage had relevance to the indicators of mathematical critical thinking skills, namely being able to analyze, formulate main problems, determine strategies, re-examine and conclude the problems given. In addition, if it is related to the PAM category, the category of high ability students contributes to an increase in mathematical critical thinking skills higher than the category of students with the moderate ability and low ability students. Furthermore, if it is related to the level of education, the mathematical critical thinking skills of junior and senior high school students through the CTL approach have increased their mathematical critical thinking skills quite well. So it can be concluded that the approach.

Keywords: Contextual Teaching and Learning (CTL), Mathematical Critical Thinking Ability

Cara Sitasi: Yasinta P., Meirista E., \& Taufik A. R (2020). Studi Literatur: Peningkatan Kemampuan Berpikir Kritis Matematis Siswa melalui Pendekatan Contextual Teaching and Learning (CTL). Asimtot: Jurnal Kependidikan Matematika, "2"("2"), "129-138. 


\section{ASIMTOT: JURNAL KEPENDIDIKAN MATEMATIKA}

\section{Volume 2 Nomor 2, Juni - November 2020, halaman 129 - 138}

Tersedia Daring pada https://journal.unwira.ac.id/index.php/ASIMTOT

Mata pelajaran matematika adalah ilmu pasti yang sangat penting dipelajari untuk setiap jenjang pendidikan sebab berpengaruh dengan kehidupan nyata seseorang. Hal ini dapat terjadi karena matematika merupakan suatu ilmu yang dapat meningkatkan kemampuan seseorang memperoleh, memilih dan mengolah informasi agar dapat menyelesaikan masalah sehari-hari yang dihadapinya dalam kehidupan. Sebagaimana dijelaskan Nuridawani, dkk (2015) bahwa matematika diajarkan, agar seseorang dapat membangkitkan kemampuan bernalar secara sistematis, logis dan kritis dalam memecahkan suatu masalah dengan mengembangkan gagasan atau ide yang dimilikinya.

Berdasarkan hasil observasi di beberapa sekolah di Merauke pada bulan September 2019, diperoleh bahwa kemampuan berpikir kritis matematis siswa dalam menyelesaikan soal matematika masih rendah. Rendahnya kemampuan berpikir kritis matematis tersebut ditunjukan dari banyaknya siswa yang melakukan kesalahan dalam penerapan konsep dasar matematika dan cara mengerjakan permasalahan yang diberikan. Hal ini mengakibatkan siswa mengerjakan permasalahan tersebut dengan tidak adanya langkah-langkah penyelesaian dan terpusat pada jawaban akhir. Akibatnya kemampuan bernalar siswa tidak dapat berkembang secara maksimal. Kemampuan bernalar tak terlepas dari kemampuan berpikir kritis. Di lain sisi, berpikir kritis matematis sangatlah penting bagi siswa karena siswa dapat memilih dengan teliti pilihan yang terbaik dan bersikap sesuai logika (Novtiar, 2017). Sunaryo dan
Fatimah (2019) dalam penelitiannya menegaskan ada 5 indikator kemampuan berpikir kritis matematis yaitu reasoning, inferensi, situation, clarity dan Overview. Sedangkan Wuningsih (2019) yaitu analisis, merumuskan, strategi dan kesimpulan.

Hasil observasi diperoleh juga bahwa dalam kegiatan pembelajaran di kelas guru masih menggunakan cara mengajar konvensional dan belum menerapkan pendekatan yang bervariasi. Kegiatan pembelajaran tersebut bersifat monoton dan guru lebih dominan di kelas sedangkan siswa hanya duduk mendengarkan penjelasan yang diberikan sehingga membuat siswa tidak dilibatkan secara langsung dalam pembelajaran dan akhirnya menimbulkan rasa bosan dan tidak tertarik untuk aktif dalam belajar. Sejalan dengan pendapat Mahmuzah (2015) yang menjelaskan bahwa salah satu faktor yang dapat membuat rendahnya suatu kemampuan berpikir kritis pada siswa adalah pembelajaran konvensional dimana guru yang lebih aktif di dalam kelas sehingga siswa menjadi kurang aktif.

Menyadari pentingnya suatu kemampuan berpikir kritis matematis siswa maka dilakukan studi literatur yang membahas, menghimpun dan menelaah kajian terdahulu tentang keterkaitan antara suatu pendekatan yang dapat membantu guru melibatkan keaktifan siswa dalam mengikuti pembelajaran. Adapun pendekatan pembelajaran yang dimaksud dalam kajian literatur ini yaitu pendekatan kontekstual atau sering dikenal dengan Contextual Teaching and Learning (CTL). Wardoyo (2013) mendefinisikan CTL sebagai suatu strategi 


\section{ASIMTOT: JURNAL KEPENDIDIKAN MATEMATIKA}

\section{Volume 2 Nomor 2, Juni - November 2020, halaman 129 - 138}

Tersedia Daring pada https://journal.unwira.ac.id/index.php/ASIMTOT

guru untuk mengaitkan bahan ajar dengan keadaan sebenarnya serta mendorong siswa melakukan suatu hubungan yang memungkinkan siswa tersebut merealisasikan pengetahuannya dalam kehidupan baik keluarga maupun bermasyarakat.

$$
\text { Majid (2016) mendefkripsikan }
$$

pembelajaran CTL kedalam beberapa tahapan yakni mengajak siswa secara sendiri mengkontruksikan pengetahuan baru yang dimilikinya agar lebih bermakna, melaksanakan inquiry pada semua topik yang diajarkan, Mengajak siswa bertanya untuk mengembangkan sifat ingin tahu, menciptakan learning community, mengilustrasikan contoh, melakukan refleksi dan menilai secara objektif kemampuan yang dimiliki siswa.

Berdasarkan penjabaran tersebut maka penelitian ini memiliki tujuan yaitu untuk memaparkan kajian literatur tentang implementasi pembelajaran matematika melalui pendekatan CTL untuk meningkatkan kemampuan berpikir kritis matematis siswa.

\section{METODE PENELITIAN}

Jenis penelitian ini yaitu studi kepustakaan (library research). Penelitian ini mengkaji pemikiran atau penemuan yang terdapat di dalam artikel sehingga menghasilkan informasi ilmiah terkait dengan pendekatan CTL dalam meningkatkan kemampuan berpikir kritis matematis siswa.

Sumber data yang ditempuh melalui riset kepustakaan yaitu suatu penelitian kepustakaan murni dengan menelaah 10 artikel. Sedangkan teknik dalam mengumpulkan data yang digunakan yaitu teknik pustaka terdiri atas mengumpulkan dan menghimpun data melalui pencarian referensi penelitian yang relevan dari jurnal yang berhubungan dengan peningkatan kemampuan berpikir kritis matematis melalui pendekatan CTL.

Adapun tahapan dalam melakukan analisis data ditempuh berdasarkan tahapan yang dikembangkan oleh Hamzah (2020) yang terdiri dari beberapa kegiatan, diantaranya:

1. Meringkas data agar mudah dipahami dan di tafsirkan secara logis dan objektif, data dapat dikaitkan serta memiliki hubungan dengan topik pembahasan lainnya. Pada bagian ini penulis meringkas beberapa literatur yang diawali dengan membaca abstrak, pendahuluan, metode serta pembahasan.

2. Data-data yang telah dikumpulkan dari bacaan dan telaah kemudian di tarik pola, tema atau topik-topik pada bab pembahasan. Pada bagian ini penulis mengambil nilai pretes, postest, dan $\mathrm{N}$-gain dari beberapa literatur, serta indikator kemampuan berpikir kritis matematis yang sama (literatur artikel Sunaryo \& Fatimah dan Wuningsih) dan tahapan-tahapan CTL (literatur artikel Syabanah).

3. Mengembangkan data yang diperoleh berdasarkan kepentingannya untuk menghindari kesalahan dalam menarik kesimpulan. Pada bagian ini penulis mengklasifikasikan literatur berdasarkan keterkaitan pendekatan pembelajaran dengan kemampuan berpikir kritis, 


\section{ASIMTOT: JURNAL KEPENDIDIKAN MATEMATIKA}

\section{Volume 2 Nomor 2, Juni - November 2020, halaman 129 - 138}

Tersedia Daring pada https://journal.unwira.ac.id/index.php/ASIMTOT

kategori PAM (pengetahuan awal matematika) dan tingkatan pendidikan.

4. Memperluas hasil temuan dengan melakukan cross check sumber dan data yang tersedia agar tidak bertumpuk.

5. Data-data yang telah dihimpun, dipaparkan apa adanya, sesuai sumber yang diperoleh. Pada bagian ini penulis memaparkan hasil-hasil analisis yang telah dihimpun menjadi suatu kajian yang menarik.

6. Menyusun kesimpulan dari hasil literatur yang dikaji.

\section{PEMBAHASAN}

\section{A. Keterkaitan antara Pendekatan CTL dan Peningkatan KBKM}

Seorang guru membutuhkan suatu pendekatan pembelajaran yang bervariasi dalam pembelajaran agar dapat meningkatkan keaktifan belajar. Salah satu pendekatan yang dapat digunakan yaitu pendekatan CTL. Selain itu CTL pun dapat mengembangkan kemampuan siswa dalam berpikir kritis matematis.

Tabel 4.1 Data Kelompok Pembelajaran CTL dan Kovensional (KV)

\begin{tabular}{|c|c|c|c|c|c|c|}
\hline \multirow[b]{3}{*}{ Peneliti } & \multicolumn{4}{|c|}{ Rata-Rata KBKM } & \multirow{2}{*}{\multicolumn{2}{|c|}{ N-Gain }} \\
\hline & \multicolumn{2}{|c|}{ Pretest } & \multicolumn{2}{|c|}{ Postest } & & \\
\hline & CTL & KV & CTL & KV & $\begin{array}{l}\text { CT } \\
\mathrm{L}\end{array}$ & KV \\
\hline $\begin{array}{l}\text { Suwanjal } \\
\text { (2016) }\end{array}$ & 6,92 & 8,08 & $\begin{array}{l}10,5 \\
0\end{array}$ & 9,85 & 0,46 & $\begin{array}{l}0,24 \\
4\end{array}$ \\
\hline Borus (2018) & $\begin{array}{l}68,9 \\
7\end{array}$ & $\begin{array}{l}68,5 \\
0\end{array}$ & $\begin{array}{l}82,7 \\
6\end{array}$ & $\begin{array}{l}77,8 \\
9\end{array}$ & 0,48 & 0,31 \\
\hline Wuningsih & 37,5 & 36,1 & 78 & 65,1 & 0,64 & 0,45 \\
\hline
\end{tabular}

\begin{tabular}{|l|l|l|l|l|l|l|}
$(2019)$ & & & & & & \\
\hline $\begin{array}{l}\text { Sunaryo \& } \\
\text { Fatimah } \\
(2019)\end{array}$ & & & 79,8 & 72,2 & & \\
\hline
\end{tabular}

Beberapa penelitian tersebut menggambarkan bahwa nilai rata-rata kelas CTL mengalami peningkatan. Meningkatnya kemampuan berpikir kritis matematis disebabkan siswa menjadikan pengalaman yang diperoleh menjadi lebih bermakna dan tertinggal diingatannya dalam hal mengkonstruksi pengetahuan yang akan diterapkan dalam kehidupan sehari-hari. Senada dengan hasil penelitian Pramono \& Daulay (2017), yang menyebutkan bahwa di dalam kegiatan pembelajaran kontekstual dapat menghasilkan belajar yang berkualitas, dapat menimbulkan tingkat kreativitas, produktivitas, efisiensi dan efektivitas yang lebih tinggi. Hal ini dikarenakan dalam pembelajaran CTL, siswa menggunakan semua alat indra yang dimiliki di waktu yang sama sehingga pembelajaran menjadi lebih nyata dan bermakna. Dengan kata lain, yang mendasari desain sebuah pembelajaran oleh seorang guru yaitu atas dasar pemikiran kebermaknaan pembelajaran yang ditimbulkan akibat dari keterkaitan antara isi pemikiran siswa dengan konteks.

Guru mendesain sebuah pembelajaran yang didasarkan oleh pemikiran bahwa kebermaknaan belajar yang muncul sebagai akibat dari hubungan antara isi dengan konteksnya. Semakin banyak keterkaitan dalam konteks yang luas maka semakin bermaknalah isi pemikiran siswa.

Sunaryo \& Fatimah (2019), dalam penelitiannya menyebutkan bahwa kebermaknaan isi pemikiran siswa dapat 


\section{ASIMTOT: JURNAL KEPENDIDIKAN MATEMATIKA}

\section{Volume 2 Nomor 2, Juni - November 2020, halaman 129 - 138}

Tersedia Daring pada https://journal.unwira.ac.id/index.php/ASIMTOT

dilihat pada hasil uraian jawaban siswa yang disusun menggunakan lima indikator dalam mengukur kemampuan berpikir kritis matematis. Indikator yang paling berkontribusi besar dan paling dominan dalam penelitian tersebut yaitu indikator Clarity dalam indikator tersebut sebesar $92 \%$ siswa dapat mengungkapkan contoh permasalahan yang mirip dengan yang diberikan. Indikator Inferensi sebesar $83 \%$ siswa mampu memperkirakan simpulan yang akan didapat. Indikator reasoning, yaitu sebesar $80 \%$ siswa dapat memberikan alasan mengenai jawaban yang telah diperolehnya. Indikator situation yaitu sebesar $79 \%$ siswa dapat mengaplikasikan konsep pengetahuan sebelumnya dalam mengerjakan permasalahan yang berhubungan dengan pelajaran ekonomi. Selanjutnya yang terakhir yaitu indikator overview yaitu sebesar 73\% siswa mampu memeriksa kebenaran jawaban. Sehingga dengan pendekatan CTL siswa menjadi terarah untuk melakukan proses berpikir kritis.

Peran mendasar dari pendekatan CTL agar siswa terbiasa mencari makna dibalik permasalahan yang ada yaitu melalui pengajuan model yang sesuai, bertanya dan proses menyelidiki (Syahbana, 2012). Dilihat dari kelebihan pendekatan CTL menurut Sariningsih (2014), proses pembejarannya lebih bermakna dan berani mengemukakan pendapat, sebab siswa mengalami sendiri atau bersentuhan langsung dengan keadaan yang disampaikan. Sejalan dengan pendapat Arifin (2016) bahwa dengan pendekatan CTL, pembelajaran bukan menjadi hanya langkah mentransfer ilmu pengetahuan yang berasal guru ke siswa saja namun akan terjadi secara alami dalam bentuk aktivitas bekerja siswa dan mengalami yang mengakibatkan pembelajaran menjadi lebih memiliki makna.

Syahbana (2012) dalam penelitian di SMPN Palembang mengenai pengembangan perangkat pembelajaran menunjukan bahwa peningkatan kemampuan berpikir kritis didukung oleh lima tahapan dalam pendekatan CTL yang dilaksanakan oleh siswa dengan bimbingan guru yaitu pada tahap constructivisme dimana siswa membangun sendiri pengetahuan berdasarkan keaktifan dalam pembelajaran berkontribusi sebesar $75 \%$. Inquiry yaitu siswa menyatakan pendapatnya sebesar $83 \%$. Questioning yaitu guru memberikan dorongan dan melakukan penilaian pada kemampuan berpikir siswa memahami materi dengan mengajak siswa untuk mengajukan pertanyaan sebesar $78 \%$. Reflection yaitu siswa dalam menyelidiki atau menemukan permasalahan dan akhirnya menyimpulkan hasil yang diperoleh sebesar $80 \%$, dan learning community yaitu siswa bekerja sama dalam kelompoknya sebesar $90 \%$.

Berdasarkan uraian diatas, dapat dikatakan proses belajar mengajar dengan CTL sangat efektif dengan rata-rata aktifitas siswa 81,2 yang menggambarkan aktifitas siswa telah sesuai dengan langkah-langkah dalam pendekatan CTL dan masuk kategori sangat baik. Amaludin \& Jazuli (2014) juga menjelaskan keterlaksanaannya kegiatan pembelajaran CTL tak terlepas dari aktifitas siswa maupun guru yang terus meningkat tiap siklusnya dimana guru berusaha seoptimal mungkin membimbing dan memfasilitasi 


\section{ASIMTOT: JURNAL KEPENDIDIKAN MATEMATIKA}

\section{Volume 2 Nomor 2, Juni - November 2020, halaman 129 - 138}

Tersedia Daring pada https://journal.unwira.ac.id/index.php/ASIMTOT

proses belajar agar siswa lebih aktif berdiskusi dan berani bertanya.

Berdasarkan pemikiran diatas, maka dapat disimpulkan bahwa untuk menjembatani munculnya KBKM maka perlulah suatu pendekatan pembelajaran. Adapun pendekatan yang dimaksud adalah CTL dimana langkah-langkah pendekatan tersebut memiliki keterkaitan dengan indikator KBKM sehingga mendorong siswa menghubungkan pengetahuannya dalam mengambil sebuah keputusan untuk menyelesaikan suatu masalah matematika.

\section{B. Peningkatan KBKM ditinjau dari}

\section{Kategori PAM}

PAM yang dimaksud dalam hasil kajian literatur ini adalah Pengetahuan Awal Matematika siswa dari setiap kategori terhadap peningkatan kemampuan berpikir kritis matematis. Menurut temuan Irawan \& Febriyanti (2016) melalui hasil deskripsi di dua sekolah (tinggi dan sedang) terhadap pendekatan CTL dan konvensional menunjukan nilai rata-rata PAM pada kelas CTL dilevel sekolah sedang sebesar 67,88 lebih rendah dari pada level sekolah tinggi sebesar 71,455. Sedangkan pada kelas konvensional (KV) nilai rata-rata sekolah tinggi sebesar 58,54 lebih baik dibandingkan sekolah sedang sebesar 45,32. Meningkatnya nilai rata-rata PAM membuktikan bahwa siswa dari level sekolah tinggi dan sedang yang menggunakan pendekatan CTL telah berjalan dengan baik. Menurutnya sangat berhubungan dengan upaya guru dalam mengelaborasi dan mengeksplorasi kemampuan siswa setiap level sekolah sehingga siswa berani mengemukakan pendapatnya dan menganalisa permasalahan dengan baik.

Berdasarkan studi pendahuluan yang dilakukan Syahbana (2012) menunjukan adanya perbedaan peningkatan kemampuan berpikir kritis matematis siswa pada setiap kategori PAM (tinggi, sedang dan rendah). Dibuktikan dengan perbedaan rata-rata $\mathrm{N}$ gain untuk kategori PAM tinggi dan sedang sebesar 0,1880, untuk kategori PAM tinggi dan rendah sebesar 0,4013 dan untuk kategori PAM sedang dan rendah sebesar 0,2132. Adapun hal yang mempengaruhi siswa kategori PAM tinggi dan sedang dapat terakomodasi dengan baik dari pada siswa kategori rendah yaitu karena siswa pada kategori PAM tinggi dan sedang lebih giat dalam mengusahakan kemampuan yang dimilikinya.

Menurut temuan Listiani, Kadir, \& Ruslan, (2017) yang menjadi dasar mengapa pengetahuan awal matematika siswa yang berkemampuan tinggi lebih baik yaitu karena siswa pada kategori tinggi menggunakan segala potensi yang dimiliki untuk memecahkan masalah yang diberikan secara mandiri. Saat siswa mengalami kendala saat menyelesaikan permasalahan yang diberikan, siswa dapat mengajukan pertanyaan kepada teman-temannya atau dapat diajukan kepada guru. Pada saat itu pula siswa dapat mentrasfer dan membagi pengetahuannya, mempertahankan pendapatnya dan menghargai pendapat orang lain. Aktivitas ini dapat meningkatkan pemahaman siswa terhadap permasalahan matematika yang 


\section{ASIMTOT: JURNAL KEPENDIDIKAN MATEMATIKA}

\section{Volume 2 Nomor 2, Juni - November 2020, halaman 129 - 138}

Tersedia Daring pada https://journal.unwira.ac.id/index.php/ASIMTOT

diberikan sehingga dapat lebih mudah diselesaikan.

Studi pendahuluan yang dilakukan Irawan \& Febriyanti (2016) menunjukan semakin tinggi pengetahuan awal yang dimiliki siswa, maka semakin tinggi pula peningkatan kemampuan berpikir kritis matematis yang diperoleh siswa. Sejalan dengan pendapat Ismaimuza (2011) yang menyebutkan bahwa terdapat perbedaan yang signifikan dalam hal peningkatan kemampuan berpikir kritis matematik berdasarkan pendekatan pembelajaran ditinjau dari PAM. Menurut Kadir \& Masi (2014) pembelajaran yang dapat mengefektifkan dan mengkontruksi pengetahuan kognitif siswa dapat membuat siswa lebih mampu melakukan seleksi, pengorganisasian, dan pengintegrasian informasi.

Berdasarkan pemikiran diatas, maka dapat disimpulkan bahwa pengetahuan awal matematika setiap kategori sangat mempengaruhi meningkatnya kemampuan berpikir kritis matematis siswa. Hal ini berarti bahwa guru harus meningkatkan kemampuan PAM siswa terlebih dahulu dengan senantiasa mengingatkan dan melatih kemampuan awal siswa agar dapat mudah meningkatkan KBKM siswa.

\section{Peningkatan KBKM Siswa SMP dan SMA}

Berpikir kritis matematis siswa SMP dan SMA merupakan awal dari proses membimbing siswa ke arah proses berpikir ilmiah. Namun hal ini tidak sebanding dengan realita yang ada yaitu masih terdapat banyak siswa yang kurang mengoptimalkan kemampuan yang dimilikinya. Menurut Syahbana (2012) hal tersebut disebabkan karena sekolah-sekolah belum mentradisikan siswanya untuk berpikir secara kritis dalam memunculkan ide-ide baru atau memikirkan

ulang kesimpulan yang sudah ada.

Mengingat pentingnya kemampuan berpikir kritis matematis siswa baik SMP dan SMA terhadap pendekatan CTL, maka pada tabel 4.2 dan 4.3 menunjukan hasil penelitian yang relevan antara siswa SMP maupun SMA pada setiap indikator kemampuan, yaitu sebagai berikut:

Tabel 4.2 Rekapitulasi Kemampuan Berpikir Kritis Matematis Siswa SMP

\begin{tabular}{|l|l|l|}
\hline \multirow{2}{*}{$\begin{array}{l}\text { Indikator KBKM } \\
\text { (Wuningsih, 2019) }\end{array}$} & \multicolumn{2}{|c|}{ SMP } \\
\cline { 2 - 3 } CTL\% & KV\% \\
\hline $\begin{array}{l}\text { Analisis } \\
\text { perumuskan pokok }\end{array}$ & 84,40 & 78,40 \\
\hline Strategi & 82,70 & 60,50 \\
\hline Menyimpulkan & 65,00 & 54,10 \\
\hline Rata- rata KBKM & 81,10 & 70,10 \\
\hline
\end{tabular}

Tabel 4.2 menunjukan indikator analisis mengalami kenaikan sebesar $6 \%$, merumuskan pokok permasalahan sebesar $22,2 \%$, Strategi sebesar $10,9 \%$ dan menyimpulkan sebesar $11 \%$, dari setiap indikator yang diperoleh dalam pembelajaran menunjukan peningkatan yang cukup baik.

Tabel 4.3 Rekapitulasi Kemampuan Berpikir

Kritis Matematis Siswa SMA

\begin{tabular}{|l|l|l|}
\hline \multirow{2}{*}{$\begin{array}{l}\text { Indikator KBKM } \\
\text { (Sunaryo \& Fatimah, 2019) }\end{array}$} & \multicolumn{2}{|c|}{ SMA } \\
\cline { 2 - 3 } & CTL\% & KV\% \\
\hline Reasoning (alasan) & 80,00 & 70,00 \\
\hline Clarity (penjelasan) & & \\
\hline
\end{tabular}




\section{$\uparrow \quad$ ASIMTOT: JURNAL KEPENDIDIKAN MATEMATIKA}

Volume 2 Nomor 2, Juni - November 2020, halaman 129 - 138

Tersedia Daring pada https://journal.unwira.ac.id/index.php/ASIMTOT

\begin{tabular}{|l|l|l|} 
& 92,00 & 85,00 \\
\hline Situation (situasi) & 79,00 & 74,00 \\
\hline Overview (pemeriksaan) & 73,00 & 70,00 \\
\hline Inferensi (kesimpulan) & 83,00 & 75,00 \\
\hline Rata- rata KBKM & $\mathbf{8 1 , 4 0}$ & $\mathbf{7 4 , 8 0}$ \\
\hline
\end{tabular}

Tabel 4.3 menunjukan indikator reasoning mengalami kenaikan sebesar $10 \%$, Clarity sebesar 7\%, Situation sebesar 5\%, Overview sebesar 3\% dan inferensi sebesar $8 \%$, dari setiap indikator yang diperoleh dalam pembelajaran menunjukan peningkatan yang cukup baik.

Indikator yang dijelaskan dalam penelitian Sunaryo \& Fatimah (2019) maupun Wuningsih (2019) memiliki keterkaitan dan telah mewakili indikator kemampuan berpikir kritis matematis yang diharapkan. Jika dilihat dari rata-rata KBKM dari masing-masing peneliti menunjukan bahwa siswa SMP memiliki rata-rata yang kurang dari siswa SMA. Hal tersebut dikarenakan siswa SMA memiliki perkembangan intelektual atau kecerdasan yang lebih baik dari pada siswa SMP, sehingga berimbas pada kesiapan dan kematanganya dalam mengambil suatu keputusan. Sejalan dengan pendapat Sunaryo \& Fatimah (2019) bahwa kecenderungan dalam kematangan proses dipengaruhi oleh usia perkembangan anak, yaitu semakin bertambah umur anak maka semakin tampak jelas kesiapannya dalam menyelesaikan persoalan.

Hasil uraian diatas juga menunjukan bahwa siswa SMP maupun siswa SMA mengalami peningkatan yang cukup baik dalam meningkatkan indikator KBKM, hal tersebut dikarenakan pendekatan CTL diawali dengan pemberian masalah yang berkaitan dengan kehidupan sehari-hari sehingga siswa mampu menuangkan ide-idenya dalam menganalisis, merumuskan, menentukan strategi, memeriksa kembali dan menyimpulkan masalah yang diberikan. Sejalan dengan temuan Irawan dan Febriyanti (2016) yang menyebutkan bahwa dalam proses pembelajaran CTL, rasa ingin tahu siswa begitu besar karena mereka mengalami proses pembelajaran matematika yang dilakukan dikelas bukan sebatas teori saja akan tetapi sangat jelas makna dan manfaatnya dalam kehidupan nyata.

Berdasarkan pemikiran diatas maka dapat disimpulkan bahwa dengan pemberian strategi yang sesuai oleh guru dan didukung dengan perkembangan anak maka peningkatan kemampuan berpikir kritis matematis baik siswa SMP maupun siswa SMA mengalami peningkatan yang cukup baik, meskipun dalam pelaksanaanya siswa SMA lebih baik dibandingkan siswa SMP.

\section{SIMPULAN DAN SARAN}

Berdasarkan hasil pembahasan studi literatur yang telah dikaji, maka diperoleh kesimpulan bahwa pendekatan CTL sangat mendukung untuk meningkatkan kemampuan berpikir kritis dalam proses pembelajaran matematika sehingga memungkin siswa menyatuhkan pengetahuan yang dimilikinya dalam menganalisis, merumuskan pokok permasalahan, menentukan strategi, menyimpulkan dan memeriksa kembali jawaban yang diberikan sesuai dengan apa yang diyakininya sebab siswa mengalami 


\section{ASIMTOT: JURNAL KEPENDIDIKAN MATEMATIKA}

\section{Volume 2 Nomor 2, Juni - November 2020, halaman 129 - 138}

Tersedia Daring pada https://journal.unwira.ac.id/index.php/ASIMTOT

sendiri apa yang menjadi fungsi dan manfaat matematika dalam kehidupan sehari-hari.

Sesuai dengan kesimpulan yang diperoleh maka disarankan kepada guru untuk dapat menerapkan pembelajaran dengan pendekatan Contextual Teaching and Learning (CTL) disekolah-sekolah karena cukup efektif membantu siswa meningkatkan kemampuan berpikir kritis matematis yang dimilikinya.

\section{DAFTAR PUSTAKA}

Amaludin, I., \& Jazuli, L. A. (2014). Meningkatkan Kemampuan Berpikir Kritis Matematika Siswa melalui Pendekatan Contextual Teaching and Learning pada Siswa Kelas VIII SMP Negeri 1 Kendari. Jurnal Penelitian Pendidikan Matematika, Vol. 2, No. 3, 29-44.

Arifin, S. (2016). Penerapan Pendekatan Contextual Teaching and Learning (CTL) untuk melihat Kemampuan Komunikasi Matematis Mahasiswa Semester Awal Pendidikan Matematika UIN Raden Fatah. Jurnal Pendidikan Matematika JPM RAFA. Vol 2, No. 2, 145.

Borus, E. M. (2018). Pengaruh Penerapan Pendekatan Kontekstual terhadap Kemampuan Berpikir Kritis Matematika Siswa SMP ST. Thomas 1 Medan. Jurnal Pendidikan Matematika, Vol. 1, No. 1, 10-24.

Hamzah, A. (2020). Metode Penelitian Kepustakaan Library Research. Malang: Literatur Nusantara.

Irawan, A., \& Febriyanti, C. (2016). Penerapan Strategi Pembelajaran
Kontekstual untuk Meningkatkan Kemampuan Berpikir Kritis Matematika . Jurnal Ilmu Pendidikan, Vol. 22, No. 1, 9-17.

Ismaimuza, D. (2011). Kemampuan Berpikir Kritis Matematis Ditinjau dari Pengetahuan Awal Siswa . Jurnal Pendidikan Matematika, Vol. 2, No. 1, 11-20.

Kadir, \& Masi, L. (2014). Penggunaan Konteks dan Pengetahuan Awal Matematika dalam Pembelajaran Keterampilan Berpikir Kreatif Siswa. Jurnal Pendidikan Matematika, Vol. 5 No. 1, 52-66.

Listiani, W. O., Kadir, \& Ruslan. (2017). Peningkatan Kemampuan Berpikir Kritis Matematik Dan Self- Efficacy Siswa Sekolah Menengah Atas Dengan Model Pembelajaran Berbasis Masalah Kontekstual. Jurnal Pendidikan Matematika, Vol. 8, No. 1, 67-77.

Mahmuzah, R. (2015). Peningkatan Kemampuan Berpikir Kritis Matematis Siswa SMP melalui Pendekatan Problem Posing. Jurnal Peluang. Vol 4, No. 1, 65-67.

Majid, A. (2016). Strategi Pembelajaran. Bandung: PT Remaja Rosdakarya.

Novtiar, C., \& Aripin, U. (2017). Meningkatkan Kemampuan Berpikir Kritis Matematis dan Kepercayaan Diri Siswa SMP melalui Pendekatan Open Ended. Jurnal Prisma Universitas Suryakancana. Vol. 6, No. 2, 120.

137 Vol 2. No 2, Juni-November 2020 
SSIMLI'

Nuridawani, Munzir, S., \& Saiman. (2015). Peningkatan Kemampuan Penalaran Matematis dan Kemandirian Belajar Siswa Madrasah Tsanawiyah (MTs) melalui Pendekatan Contextual Teaching and Learning (CTL). Jurnal Didaktik Matematika. Vol. 2, No. 2, 62.

Pramono, E. S., \& Daulay, A. S. (2017). Penerapan Pendekatan Contextual Teaching and Learning (CTL) dalam Upaya Meningkatkan Kreativitas dan Berpikir Kritis Siswa Kelas X Di SMA Negeri 3 Padangsidimpuan Pokok Bahasan Bangun Ruang. Jurnal Logaritma Vol. 5, No. 02 , 6376.

Sariningsih, R. (2014). Pendekatan Kontekstual untuk Meningkatkan Kemampuan Pemahaman Matematis siswa SMP. Jurnal Infinity, Vol. 3, No. 2, 156-157.

Sunaryo, Y., \& Fatimah, A. T. (2019). Pendekatan Kontekstual dengan Scaffolding untuk Meningkatkan Kemampuan Berpikir Kritis Matematis. Jurnal Nasional Pendidikan Matematika, Vol. 3, No. 1, 67-79.

Suwanjal, U. (2016). Pengaruh Penerapan Pendekatan Kontekstual terhadap Kemampuan Berpikir Kritis Matematis Siswa SMP . Jurnal Pendidikan Matematika FKIP Univ. Muhammadiyah Metro, Vol. 5, No. 1, 61-67.

Syahbana, A. (2012). Pengembangan Perangkat Pembelajaran Berbasis
Kontekstual untuk Mengukur Kemampuan Berpikir Kritis Matematis Siswa SMP . Jurnal Edumatica, Vol. 02, No. 02, 17-26.

Wardoyo, S. M. (2013). Pembelajaran Kontruktivisme. Bandung: Alfabeta.

Wuningsih. (2019). Efektivitas Pendekatan Problem Posing dan Kontekstual Ditinjau dari Kemampuan Berpikir Kritis dan Kreatif Siswa. Journal of Mathematical Science and Mathematics Education, Vol.01 No. 01, 125-134. 